\title{
Jødisk og palæstinensisk nationalismes parallelle spor
}

Herbert Pundik

\section{Palæstina-konflikten begyndte som en kamp om jord mellem jødiske socialistiske pionerer og for- drevne arabiske daglejere. I dag, 100 år senere, udkæmpes den mellem to nationale selvstændig- hedsbevægelser, men det centrale motiv er stadig kampen om jord}

I 1905 oprettede en kristen araber fra Jerusalem et selskab i Paris til fremme af arabisk patriotisme. Palæstina var dengang en del af den syriske provins i det osmanniske imperium. Kort efter udgav han en bog med titlen La Réveil de la Nation Arab. Her kan man finde følgende profetiske ord:

"To betydningsfulde fænomener af ensartet karakter, og dog vendt mod hinanden, er for nærværende i færd med at manifestere sig i det asiatiske Tyrki. Det drejer sig om den gryende arabiske nations bevidsthed, og de latente bestræbelser fra jødernes side på at genetablere Israels gamle rige i stor målestok. De to bevægelser er bestemt til at bekæmpe hinanden uophørligt, indtil den ene er blevet knust af den anden".

Det var godt set, for på det tidspunkt boede kun ca. 30.000 jøder i Palæstina. Størstedelen var ortodokse, der boede i Jerusalem og andre byer med tilknytning til jødisk religion og historie. Resten var indvandrere fra Østeuropa, der fra midten af 1880 'erne var kommet til Palæstina på flugt fra antisemitiske optøjer og for at starte en ny tilværelse som landmænd. De blev finansieret af Baron Edmond de Rothschild i Paris.

De var det, man kunne kalde gentleman-farmere, idet de drev deres vingårde og appelsinplantager ved hjælp af arabisk arbejdskraft. Om kolonisering med det formål at oprette en jødisk stat var der ikke 
tale. Indvandring i Palæstina var et spørgsmål om religiøs selvrealisering.

Det er vigtigt at slå fast, for konflikten mellem den arabiske befolkning og de jødiske indvandrere, som senere skulle udvikle sig til et sammenstød mellem de to nationale selvstændighedsbevægelser - den zionistiske og den palæstinensiske udsprang ikke af arabisk protest mod denne første bølge af indvandrere fra slutningen af 1880'erne, der ikke var politisk motiveret, men spirituel.

Den blev udløst af den anden bølge, der kom til Palæstina i perioden fra 1905 til første verdenskrigs udbrud, den såkaldte pionerindvandring, der bestod af unge fra socialistiske zionistiske bevægelser. Den ene var socialdemokratisk, den anden hældede mere i marxistisk retning.

Flere end et par millioner jøder valgte flugt i disse år fra det Rusland, som Lenin kaldte 'folkeslagenes fængsel'. Det store flertal søgte over Atlanten til det, de på det jødiske folkesprog 'jiddisch' kaldte 'die goldene medine', det gyldne land.

Ca. 50.000 valgte vejen over Middelhavet til Palæstina. De var inspireret af den zionistiske tanke, der opstod i slutningen af det 19. århundrede som en udløber af den nationale vækkelse, der havde grebet andre mindretal i Europa - polakkerne og serberne, finnerne og tjekkerne. Af alle folkeslag i Europa, der søgte national frigørelse, var jøderne de sidste, som lod sig drage af den nationale idé. Længe klyngede jøderne sig til håbet om at humanistisk oplysning ville sejre over antisemitismen.

Hvis frihed fra diskrimination og forfølgelse havde været en realistisk mulighed, ville zionismen, dvs. tanken om en jødisk stat i Palæstina, aldrig være opstået som en politisk bevægelse.

\section{Zionismen et selvforsvar}

Zionismen var et udtryk for selvforsvar. Berl Katznelson, der efter ankomsten til Palæstina i 1905 blev en af arbejderbevægelsens førende ideologer, forklarede sin beslutning om at udvandre til Palæstina med ordene: "Det er ikke på grund af zionistisk overbevisning, men på grund af modviljen mod at tilhøre en generation, som ikke engang har styrke nok til at dø en ærefuld død”.

Jøderne i Rusland boede for 90 procents vedkommende i den såkaldte 'jødezone', der omfattede de områder, vi i dag kender som Ukraine, Hviderusland og Polen. Ifølge en russisk regeringsrapport udgjorde indbyggerne i jødezonen "et proletariat, der er fattigere og mere miserabelt end noget andet i Rusland".

De var genstand for skiftende zarer og deres rådgiveres vilkårlighed. I jødezonen, hvor der boede fem millioner jøder, måtte jøder kun udgøre 10 pct. af eleverne på gymnasi- 


\section{HERBERT PUNDIK}

erne. Alexander den Første gav jøderne lov til frit at vælge uddannelse og at lade sig indskrive på universiteter og gymnasier, for senere at skifte mening, tvinge dem til at opgive deres liberale erhverv og vende tilbage til jødezonen. En anden zar opmuntrede jøderne til at blive bønder, men nægtede dem retten til at eje jord, og Nikolaj den Første indførte 25 års militærtjeneste for jøder, Alexander d. II's nærmeste rådgiver, Constantin Pobedonostesev syntes, han havde fundet en genial løsning på det jødiske problem i Rusland: udvis en tredjedel, tvangsomvend en tredjedel og dræb resten.

Det var vilkårene for jøderne i Rusland i anden halvdel af 1880 'erne og begyndelsen af de 20. århundrede.

Det var disse forhold ud over armod, der drev jøder på flugt over Atlanten og over Middelhavet.

Min bedstefar, der var hattemager, kom hverken over det ene eller det andet hav. Han flygtede i 1905 fra den flække i Ukraine, hvorfra min familie stammer. Han ville til USA, men pengene rakte ikke, og familien endte i Majonæsekvarteret i København. Han var ortodoks jøde og zion-elsker, men på sikker afstand som de fleste andre jøder i Rusland.

Som nævnt vovede kun 40-50.000 at udvandre til Palæstina i perioden fra 1905 til 1914.

90 pct. af disse døde eller flygtede videre ud i verden fra det ugæstfrie land i det osmanniske imperium. To tusinde unge mænd og kvinder holdt ud og lagde grunden til den jødiske stat. Blandt dem var David Ben-Gurion, Israels første statsminister.

De slog sig ned som landmænd, ikke af tilbøjelighed, men af ideologiske grunde. De havde ingen landbrugserfaring, men var drevet af den tanke, at antisemitismen bl.a. var en reaktion på jødernes ikkenormale beskæftigelsesstruktur i Rusland som handlende og mellemmænd. De ønskede at starte helt forfra med hakke, skovl og spade og skabe en helt ny jøde.

Det hebraiske ord 'avoda' har en dobbelt betydning. Det betyder både 'fysisk arbejde' og 'tilbedelse'. De tilbad arbejde, de gik ind for ekstrem kollektivisme, afviste enhver privat ejendomsret, og praktiserede fuld ligestilling mellem mænd og kvinder i deres kollektive samfund, kibbutzerne.

Deres sange fortæller mere end mange forklaringer:

Vi er pionerer på de brandende marker på de golde ødemarker De første til at komme Som svalerne om foråret vil vi dakke de støvede marker med et gyldent flor

De var en flok romantiske fanatikere med en historisk mission.

\section{Arabiske jordarbejdere i klemme}

Men hvad med araberne? Hvordan forholdt pionererne sig til den ind- 
fødte befolkning, der dengang måske talte en halv million mennesker? Det store flertal af dem var fattige bønder eller jordløse daglejere, der arbejdede for godsejere, som i reglen boede i byerne eller udlandet.

Tendensen til storbrug i Palæstina var resultatet af en tyrkisk jordreform, hvis primære formål var at registrere ejerskab til jorden i Palæstina.

Store områder af statsjord blev traditionelt dyrket af bønder der havde hævd til jorden og havde haft det i generationer uden, at de havde tinglyst denne ret for at undgå at betale afgift til staten. Den jord blev nu registreret af tyrkiske embedsmænd, arabiske købmænd i byerne, sheiker og andre med forbindelserne i orden, og bønderne blev reduceret til daglejere, der måtte nøjes med en halvdel eller en tredjedel af høsten.

Jeg nævner dette forhold lidt detaljeret, fordi det er vigtigt til forståelse af årsagerne til de første sammenstød mellem araberne og de nye indvandrere, arbejdspionererne der begyndte at komme i 1905. Den stenede eller sumpede jord de med så stor entusiasme begyndte at betvinge, havde det nyoprettede jødiske nationalfond købt af tyrkiske embedsmænd eller arabiske ejere, nu og da også af kristne gejstlige, især de græsk-ortodokse, der er blandt de største jordejere i nutidens Israel, kendt for deres korrupte praksis.

De arabiske daglejere blev følgelig fordrevet fra den jord, de havde dyrket, af de socialistiske arbejdspionerer, der fordrev dem helt i overensstemmelse med deres ideologi, som forbød dem at udnytte fremmed arbejdskraft.

Pionererne havde svært ved at se det paradoksale i situationen. De var kommet til det nye land for at opbygge et idealsamfund bygget på "kærlighed, frivillighed og harmonisk samarbejde mellem frie mænd", som den første zionistiske kommunist, Moses Hess, der var samtidig med Marx og Engels, skrev i bogen Rom og Jerusalem allerede i 1862.

Prisen betalte de fordrevne arabiske daglejere. Der er ikke mange tegn på eftertanke over denne paradoksale situation i de talrige erindringsbøger, som medlemmer af pionergenerationen, der senere blev det selvstændige Israels elite, skrev.

Efterhånden som det stod klart, at de havde forårsaget en revolution $\mathrm{i}$ de arabiske daglejeres tilværelse, og efterhånden som antallet af sammenstød mellem arabere og pionerer voksede, trådte deres ideologiske forsvarsmekanisme i kraft.

De mente at repræsentere fremskridtet, og den arabiske modstand skyldes kun feudalherrerne, der i egen interesse opmuntrede araberne til at angribe pionererne. Når først feudalherrerne var fjernet, ville befolkningen forstå hvilke fremskridt den zionistiske indvandring ville bringe dem.

Pionerernes ideologiske blindhed 


\section{HERBERT PUNDIK}

var i smuk overensstemmelse med samtidens opfattelse af kolonialismen. De var børn af deres tid.

Både Marx og Engels anså kolonialismen for at være en nødvendig forudsætning for socialismen. De betragtede de indfødte i Asien og Afrika som 'barbarer', og Marx var af den mening, at de ikke havde nogen historie.

Araberne i Palæstina var undertrykte mennesker, der skulle befries, og befrielsen var på vej i form af jødisk socialisme, mente pionererne.

Denne forklaring forekommer overbevisende for den, der har oplevet fænomenet ideologisk blindhed i Europa i 1930'erne og de efterfølgende årtier.

Det blev imidlertid sværere og sværere at ignorere den voksende modstand mod det zionistiske projekt i Palæstina, især efter 1908, dvs. efter den ungtyrkiske revolution.

Palæstinensiske arabere var nu repræsenteret af fem medlemmer i det tyrkiske parlament, og pressecensuren i Palæstina blev ophævet. Som resultat dukkede modstanden mod indvandringen op på overfladen. Den fik stemme, i skrift og tale.

\section{De første sammenstød}

I 1907 oprettede pionererne den første jødiske forsvarsorganisation, Hashomer, forløberen for modstandsorganisationen Haganah og den israelske hær.
Aktiv modstand mod jødisk indvandring kan således dateres til de første sammenstød mellem pionererne og de jordløse arabiske daglejere. Det er ikke tilfældigt at Yassir Arafat valgte daglejernes hovedbeklædning, keffiyeh, som den palæstinensiske guerillas kendetegn.

Bondeoprøret vandt genklang blandt Jerusalems og de øvrige større byers arabiske elite, journalister, lærere og andre med uddannelse, men endnu er det for tidligt at tale om en palæstinensisk nationalisme eller identitet. Det var en kamp om jorden.

Palæstina var en del af det sydlige Syrien, der var en provins i det osmanniske imperium. En persons identitet var først og fremmest forbundet med den udvidede familie, hamullaen, med landsbyen og det religiøse tilhørsforhold, muslim eller kristen. Dernæst tilhørte man det arabiske fællesskab, ummáen, og indtil det osmanniske imperiums sammenbrud under Første Verdenskrig, definerede nogle medlemmer af den arabiske elite, især førende familier i Palæstina, sig ikke som arabere, men som osmanner.

Modstandere af det tyrkiske vælde definerede sig hverken som syrere eller irakere, men som arabiske nationalister.

David Ben-Gurion skriver mange år senere, i 1960'erne, at han først blev opmærksom på nationalistiske følelser blandt araberne i Palæstina i 1915. 
Han sad i fængsel i Jerusalem, arresteret af de tyrkiske myndigheder. I fængslet møder han en araber, som han kendte fra sin studietid i Istanbul, hvor de begge havde læst jura.

"Hvorfor sidder du her?" spurgte araberen.

Ben-Gurion svarede at det var på grund af zionistisk aktivitet.

"Som ven gør det mig ondt", svarede araberen, "men som araber glæder det mig".

Ben-Gurion fortalte, at bemærkningen "kom som en bombe", men den ændrede ikke hans opfattelse af, at araberne i Palæstina ikke var en nation, men tilhørte det store arabiske fællesskab, ummaen.

Denne fordom om at der ikke var noget, der hed en palæstinensisk national identitet, forblev det officielle Israels standpunkt indtil Oslo-aftalen, der blev truffet i september 1993 mellem Israel og PLO, den palæstinensiske befrielsesbevægelse, efter hemmelige møder i Norge.

Holdningen var igen udtryk for ideologisk blindhed. Det var så vigtigt for zionisterne at bevare illusionen om, at den jødiske nationalbevægelse ikke var kommet til Palæstina for at oprette en stat på bekostning af den anden nation, at man var nødt til at benægte fakta og usynliggøre palæstinenserne som nation. I modsat fald var det ensbetydende med, at man delegitimerede zionismen som et moralsk forsvarligt projekt.
Jeg husker, hvorledes jeg som ung reporter på det israelske LO's dagblad, Davar, blev kaldt til afklapsning i 1969 hos arbejderpartiets førende ideologiske vagthund, Israel Galili, fordi jeg i en artikel havde kaldt palæstinenserne i de besatte områder, som Israel have erobret et par år før, 'en nation'.

Golda Meir, der dengang var statsminister, lagde for med denne udtalelse til en engelsk søndagsavis: "Der var ikke noget der hed palæstinensere. De eksisterede ikke".

\section{Balfour-deklarationen}

Mange år tidligere, i 1917, udstedte den engelske regering den såkaldte Balfour-deklaration, hvor Hans Majestæts regering forpligtede sig til at arbejde for oprettelsen af et jødisk nationalhjem i Palæstina.

Samme år erobrede engelske styrker Jerusalem og resten af Palæstina, og i 1920 overdrog Folkeforbundet mandatet over Palæstina til Storbritannien. Balfour-deklarationens principper blev inkorporeret i mandatet. På dette tidspunkt boede der 80.000 jøder i Palæstina. Ifølge et arabisk skøn udgjorde de 10 pct. af befolkningen.

Der findes kun få arabiske kilder, der dokumenterer reaktionen på Balfour-deklarationen i Palæstina. Aviserne var underkastet engelsk militærcensur indtil 1920 med indførelse af et civilt styre.

Landet var forarmet efter krigen 


\section{HERBERT PUNDIK}

og det osmanniske riges sammenbrud. Den politiske forvirring var stor.

Irak blev et kongedømme med et parlament. Syrien blev først et kongerige under kong Feysal, som, efter at franskmændene havde fordrevet ham fra tronen i Damaskus, blev konge af Irak. Transjordanien blev separeret fra Palæstina i 1921 og blev et emirat underlagt engelsk kontrol, formelt regeret af emir senere kong Abdallah. Palæstina var et særligt tilfælde, fordi befolkningen i modsætning til de andre nye arabiske lande skabt på ruinerne af det osmanniske imperium end ikke fik illusionen af national selvbestemmelse ligesom de andre arabere.

Set fra et arabisk synspunkt var årsagen til denne særbehandling Balfour-deklarationen og hensynet til jøderne, der var blevet lovet et nationalhjem. På engelsk lød 'a national home' måske ikke frygtindgydende, men i arabisk oversættelse kunne udtrykket fortolkes som en stat.

I 1920 udbrød de første antijødiske uroligheder i Palæstina, og de gentog sig i 1929. De blev nedkæmpet af det engelske militær samtidig med, at indvandringen voksede i takt med, at forholdene for jøder, først i Polen under depressionen i 1920'erne og senere i Tyskland efter Hitlers magtovertagelse i 1933, blev mere og mere kritiske. Verden var delt i to dele, sagde lederen for den zionistiske verdensbevægelse, professor Chaim Weizmann: de lande hvor jøderne ikke kunne leve i sik- kerhed, og de lande der ikke ville modtage dem som immigranter.

Undtagelsen var Palæstina. I perioden 1922-1936 firedobledes den jødiske befolkning i Palæstina. Tilsvarende voksede arabernes frygt for fremtiden.

I 1935 dræbte engelske soldater i Haifa en af lederne af det arabiske bondeoprør. Hans navn var Al-Qassam, og han har navngivet de raketter, som den palæstinensiske Hamasbevægelse i dag affyrer mod israelske landsbyer og byer i nærheden af Gazaområdet.

Begravelsen udløste store demonstrationer rettet mod den voksende jødiske indvandring, og i 1936 udbrød den første landsdækkende opstand, der varede $i$ tre år. En overgang mistede englænderne kontrollen med en del af Palæstina.

Opstanden blev en katastrofe for araberne. Den kostede ca. 5.000 arabere livet.

Revolten skabte splid i den arabiske politiske ledelse i Jerusalem. En del af de politiske ledere blev udvist af englænderne, andre flygtede til udlandet og vendte aldrig tilbage. Stormuftien Amin al-Husseini, en af revoltens ledere, flygtede først til Libanon og senere til Tyskland, hvor han tilbragte krigen som Hitlers gæst

\section{Kompromis ikke muligt}

Det arabiske oprør fra 1936-39 understregede den kendsgerning, som 
allerede var slået fast med sammenstødene mellem araberne og jøderne i 1929. Balfour-deklarationens løfte til jøderne om et nationalhjem i Palæstina var ikke gennemførligt på fredelig vis. En konflikt var uundgåelig. I erkendelse heraf erklærede Chaim Weizman, præsidenten for den zionistiske verdensbevægelse, allerede i 1933: "Jeg har hverken forståelse eller sympati for tanken om et jødisk flertal i Palæstina”. Udtalelsen vakte så stort oprør, at Weizmann måtte træde tilbage fra posten. Ben-Gurion drog en anden konklusion af sammenstødene i 1929. "Vi har syndet i 2000 år", sagde han, "og vor synd er svaghed. Vi er svage, det er vores forbrydelse".

Blandt de egenskaber der karakteriserede Ben-Gurion var mod til klarsyn. Han vidste, at en konfrontation var uundgåelig, fordi han forstod Palæstina-arabernes frygt for det zionistiske projekt. Han nærede ingen illusioner om, at et kompromis var muligt.

Efter en frugtesløs forhandling med den arabisk leder, Moussa Alami, sagde Ben-Gurion, at han i Alamis sted ville have været lige så afvisende.

Samme realistiske erkendelse af de arabiske motiver for at bekæmpe zionismen kender man fra Yitzhak Rabin, den israelske statschef, der i 1993 i Oslo - som den første israelske leder - førte forhandlinger med den palæstinensiske befrielsesbevægelse. "Hvis jeg var palæstinenser, ville jeg også være partisan”, har han udtalt.

Man kan spørge, hvordan disse to, som er repræsentative for talrige israelere med samvittigheden i orden, kunne forene deres forståelse for den arabiske side af konflikten med en målbevidst stræben efter at virke i deres egen sags tjeneste.

Svaret finder man i en udtalelse af Ben-Gurion.

"Hvis det er en uretfærdighed mod araberne at lade jøderne komme til Palæstina, så er det en endnu større uretfærdighed mod jøderne af formene dem adgang".

En gruppe ledende jødiske intellektuelle og pacifister i kredsen omkring det hebraiske universitet i Jerusalem opererede i slutningen af 1920'erne med muligheden for et kompromis mellem de to nationale bevægelser - en binational stat. Én stat for to nationer. En løsning som blev afvist af selv de mest moderate arabere, men i dag atter er blevet aktuel blandt palæstinensiske intellektuelle, der har opgivet troen mod en tostatsløsning. Jehuda Magnes, der var rektor for universitetet, fortæller, hvorledes han blev overbevist om, at tanken var uigennemførlig selv i de mest moderate araberes øjne.

Magnes forsøgte at rekruttere Khalil a-Sakkanini, en moderat arabisk intellektuel i Jerusalem, for tanken om en binational stat. Sakkanini afviste ideen med en anekdote: En araber kommer ridende på sit æsel 


\section{HERBERT PUNDIK}

og passerer en gående jøde. Da de skulle i samme retning tilbød han ham en plads på æslet.

"Jatak, men er det ikke for tungt for dit æsel?”

"Nej", lød svaret.

Efter en stund viste æslet tegn på træthed, og vandringsmanden siger til ejeren: "Jeg tror nu alligevel, at det er for meget for vort æesel".

Ejeren byder ham at stå af.

"Hvorfor".

"Det skal jeg sige dig", svarer ejeren. "Det er ikke af hensyn til æslet. Men første gang talte du om mit æsel. Anden gang talte du allerede om vort æsel".

\section{Et tidligt delingsforslag}

I september 1936 nedsatte den britiske regering en kommission, opkaldt efter formanden Lord Robert Peel. Dens opgave var at komme med forslag mht. det engelske Palæstina-mandats fremtid. Det var klart, at de løfter, som englænderne havde givet jøderne og araberne, var uforenelige. På det tidspunkt boede 400.000 jøder og en million arabere i Palæstina.

Løsningen var deling. Jødisk indvandring skulle reduceres til 12.000 pr. år i de kommende fem år.

Den jødiske del skulle omfatte kystområdet lidt syd for Tel Aviv plus Galilæa. For i videst muligt omfang at gøre de to lande befolkningsmæssigt homogene, forestillede rapportens fædre sig en større befolknings- udveksling i lighed med den græsktyrkiske efter Første Verdenskrig. Jøderne accepterede den i juli 1937. De arabiske ledere udtalte deres første officielle nej til en kompromisløsning. En holdning, der kom til at danne skole indtil 1988, da lederen af den palæstinensiske befrielsesorganisation, PLO, Yassir Arafat accepterede en palæstinensisk stat på kun 22 pct. af Palæstinas areal og anerkendte Israel.

Peel-kommisionens delingsplan ville have givet araberne ca. 75 pct. af Palæstina.

En afgørende grund til, at planen blev vedtaget af 75 pct af de jødiske delegerede ved en verdenskongres, var håbet om at kunne bringe det størst mulige antal jøder fra Europa til Palæstina, først og fremmest de tyske, der talte 500.000.

I 1939 udgav Storbritannien en ny hvidbog, der i realiteten annullerede Balfour-deklarationen og accepterede det arabiske standpunkt i konflikten om Palæstina. Jøderne skulle forblive et mindretal. Deling kom ikke på tale. Verdenskrigen nærmede sig, og hvidbogen, der bar Neville Chamberlains underskrift, blev opfattet som den endelige likvidation af det zionistiske projekt.

Den var et britisk fors $\varnothing g$ på at pacificere kritikken i de arabiske lande, som englænderne måske ikke uden grund frygtede ville gøre fælles sag med Tyskland og Italien, hvis verdenskrigen bredte sig til Mellemøsten. 
Det var realpolitik, så det battede. Om den virkede efter hensigten, er svært at udtale sig om. Araberne gjorde som helhed ikke oprør mod de allieredes interesser i Mellemøsten. Om hvidbogen virkede efter den kyniske hensigt og bidrog til at forhindre en arabisk-aksemagtalliance er gætværk. Hvad der derimod kan konstateres, er den klare sammenhæng mellem skiftet i engelsk politik og omfanget af Hitlers folkemord på Europas jøder.

Set fra et arabisk synspunkt var hvidbogen af 1939 en sejr. Den dømte jøderne til en permanent stilling som mindretal i Palæstina, fordi den stipulerede, at efter fem år skulle jødisk indvandring afhænge af arabisk tilladelse. Den lovede palæstinensisk selvstyre efter fem år og selvstændighed efter ti år.

Ikke desto mindre blev den afvist af den palæstinensiske højkomité dikteret af stormufien Amin el Husseini, der havde slået sig ned i Beirut.

Nogle palæstinensiske historikere er af den opfattelse, at stormuftien afviste hvidbogen på grund af jalousi rettet mod de kræfter blandt de ledende familier i Jerusalem, der ønskede at acceptere den og samarbejde med englænderne.

\section{Fra delingsplan til krig}

\section{1947 opgav England mandatet} over Palæstina, og i november dette år vedtog FN's generalforsamling en plan om at dele Palæstina i to stater,
55 pct. til jøderne og 45 pct. til palæstinenserne. Jøderne accepterede delingsplanen, men for tredje gang lød der et arabisk nej til et kompromis, artikuleret af magthaverne i de syv lande, anført af Egypten, der dengang udgjorde den arabiske liga.

Modstanden mod FN's delingsplan udløste allerede i december 1947 en guerillakrig mod det jødiske samfund i Palæstina, som nu talte ca. 600.000 indbyggere.

I syd kæmpede egyptiske frivillige for deres muslimske brødre, i nord kæmpede den arabiske befrielsesarmé og i den centrale del af Palæstina kæmpede guerillaer organiseret af den tidligere stormufti Amin Husseini.

Den arabiske højkomité i Jerusalem var ude af stand til at koordinere modstanden bl.a. på grund af manglende ledelse og indre modsætninger. Haifa faldt i april og Jaffa den 14. maj, den dag den jødiske stat blev proklameret, og de militære styrker fra Egypten, Syrien, Irak og Jordan angreb den nye stat. Den var i overhængende fare i de første fire uger, men en FN dikteret våbenhvile fra midt $i$ juni til midt i juli 1948 gav israelerne et nødvendigt pusterum til at bringe våben ind fra Tjekkoslovakiet og reorganisere hæren. Den 15. juli gik israelerne i offensiven, og da krigen sluttede efter ca. 12 måneder havde israelerne ikke blot forsvaret de 55 pct. som FN-delingsplanen havde tildelt dem, men erobret yderligere 23 pct. 
Resten, 22 pct., kunne være blevet en palæstinensisk stat allerede i 1949, men blev annekteret af kongeriget Transjordan.

De 22 pct. erobrede Israel under Seksdageskrigen i 1967, således at Israel siden har kontrolleret hele $\mathrm{Pa}-$ læstina mellem Middelhavet og Jordanfloden.

\section{Fra krig til flugt}

Som beskrevet, opstod den jødiske nationale selvstændighedsbevægelse i praksis i 1905 med pionerindvandringen fra $\emptyset$ steuropa. Den palæstinensiske opstod først med Yassir Arafats organisering af modstandsbevægelsen Fatah i 1959 og senere med hans overtagelse af kontrollen med PLO, den Palæstinensiske Befrielses-Organisation.

Først da optrådte en autentisk palæstinensisk leder i den over 100 år lange konflikt om Palæstina. Først under Arafat, selvom det skete sent, blev væbnet modstand en taktik underlagt et strategisk mål, oprettelsen af en palæstinensisk stat.

Den arabiske modstand havde indtil da været koncentreret om det negative mål at hindre jøder $i$ at indvandre, købe jord og oprette en stat.

Effendierne, de traditionelle magthavere, det muslimske præsteskab med stormuftien i spidsen og nej-politikkens talmænd, var de første der flygtede, da guerillakrigen udbrød, efter at FN havde vedtaget delingsplanen i november 1947. De overlod den palæstinensiske befolkning til sig selv, da den israelske selvstændighedskrig som araberne kalder naqba en - katastrofen - rasede fra 1948-49.

Krigen bragte den palæstinensiske befolkning i en choktilstand. Ca. 650.000 enten flygtede fra de områder, der kom under israelsk styre, eller blev fordrevet i et bevidst forsøg fra israelsk side på at reducere antallet af arabere i Israel.

Den tilbageblevne palæstinensiske befolkning var, demoraliseret og forladt af sine ledere, henvist til at kæmpe for tilværelsen uden at have tanke for modstand mod den israelske besættelsesmagt eller for politisk organisation.

Arafat startede således fra bunden, da han samlede de palæstinensiske skår og ud af virvaret efter den første krig i 1948-49 samlede palæstinenserne omkring idéen om, at de var en nation.

\section{Gensidig anerkendelse}

Efter 50 år fik palæstinensernes kamp et konstruktivt sigte, en palæstinensisk stat.

Man kan have større eller mindre sympati for den ene eller en anden part i konflikten, større eller mindre forståelse for den arabiske modstand mod det zionistiske projekt, men man kan ikke afvise den arabiske indsigelse om, at antisemitismen er et europæisk-kristent problem, ikke et arabisk, og at i det omfang, 
hvor zionismen er et forsvar mod antisemitisme, er det ikke retfærdigt at løse problemet på arabisk bekostning.

Arabisk nej-sigeri til skiftende kompromisforslag har været jødernes bedste forbundsfælle. Havde de arabiske ledere accepteret Peel-planen i 1936 ville der næppe have eksisteret en jødisk stat i dag, fordi en stat med 25 pct. af Palæstina ikke ville have været levedygtig.

Og hvis araberne havde accepteret FN's delingsplan af 1947, ville en jødisk stat i halvdelen af Palæstina, delt i tre dele, der ikke dannede et territorialt, sammenhængende hele, ikke have overlevet i det lange løb.

De hemmelige møder i Oslo i 1993 mellem israelske og palæstinensiske repræsentanter er det historiske vendepunkt, hvor begge parter for første gang erkendte den væbnede kamps utilstrækkelighed.

Arafat indså, at han ikke kunne likvidere Israel, og statsminister Yitzhak Rabin indså, at han ikke kunne nedkæmpe den palæstinensiske modstand mod den israelske besættelse.

Oslo-aftalen løste ikke konflikten om Palæstinas deling, men blev forudsætningen for en løsning, for i Oslo besluttede de to nationale selvstændighedsbevægelser at anerkende hinanden som legitime for første gang i historien.
Oslo var forudsætningen for Camp David i 2000 under Bill Clintons formandskab, og Camp David var forudsætningen for de halvofficielle forhandlinger i Geneve for fire år siden. Og Geneve-aftalen dannede igen grundlaget for forhandlingerne mellem nu afgåede ministerpræsident Ehud Olmert og det palæstinensiske selvstyres præsident, Mahmoud Abbas.

Skridt for skridt rykker målet nærmere. Afstanden fra Oslo og Geneve til fred er kortere end den afstand, der allerede er tilbagelagt, fra det første palæstinensiske bondeoprør i 1920 til Oslo i 1993.

Det kritiske spørgsmål efter det israelske valg 10. februar 2009 er, om den nye israelske regering vil tilpasse sig den aktuelle politiske virkelighed og udnytte de muligheder, som den seneste udvikling i Mellemøsten - bl.a. fremsættelsen af et fælles arabisk fredsforslag i 2005 - og valget af Barack Obama har åbnet, eller om den vil overtage det arabiske nejsigeri med de samme katastrofale konsekvenser, som det fik for palæstinenserne.

Herbert Pundik er seniorkorrespondent på Politiken. Artiklen bygger på hans tiltradelsesforelasning som adjungeret professor ved Ålborg Universitets Institut for Historie, Internationale Studier og Samfundsforhold. 


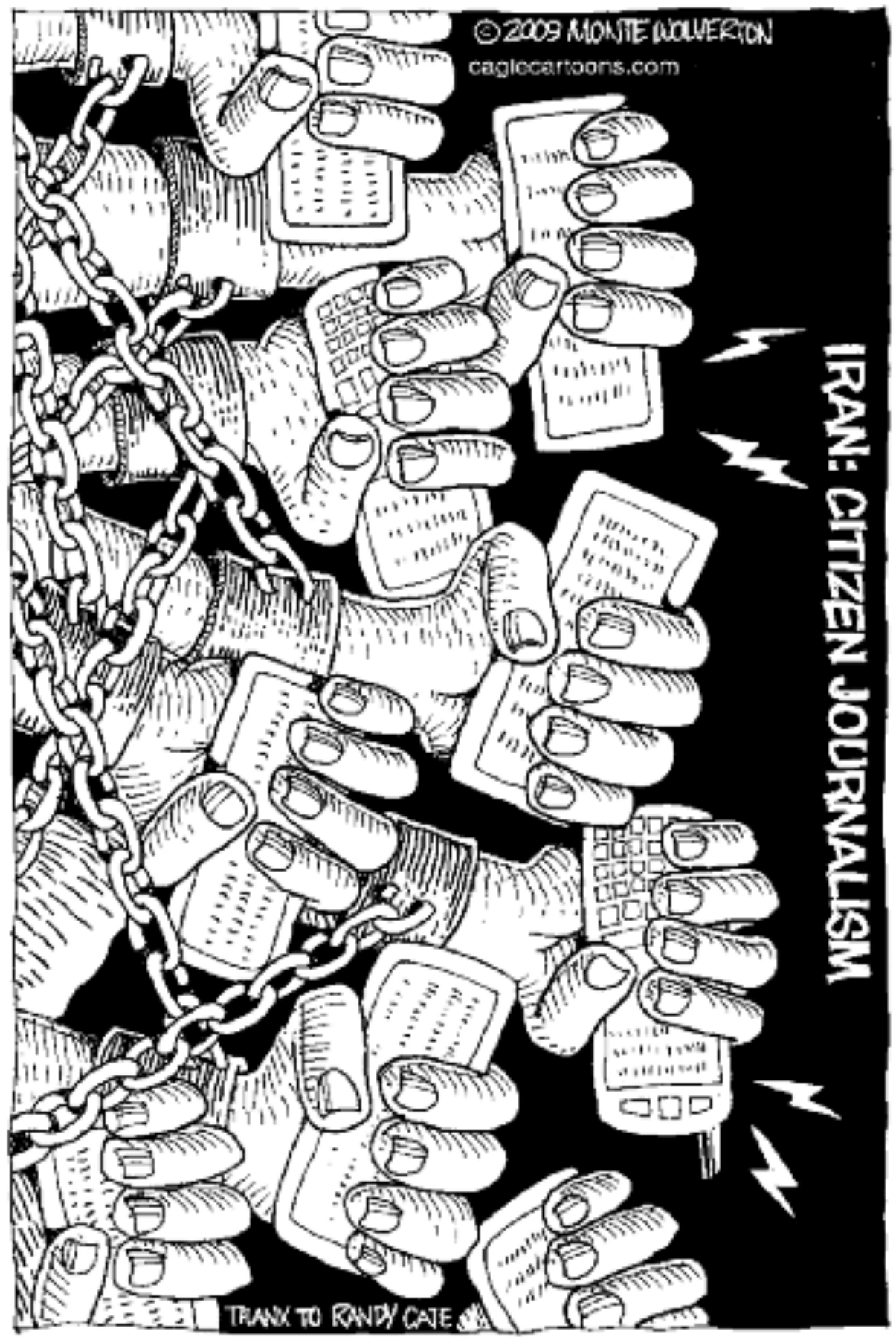

